\title{
Factors affecting private rangeland lease rates
}

\author{
LARRY W. VANTASSELL AND SCOTT M. MCNELEY
}

Authors are associate professor and research assistant, Dept, of Agricultural Economics, University of Wyoming, Laramie, Wyo. 82071-3354.

\section{Resumen}

\section{Abstract}

Private rangeland lease rates have been used historically as an indication of the price of public grazing lease rates. The ability of these prices to adequately reflect short-term fluctuations in the rancher's ability to pay for forage has been questioned by policy makers and researchers. Multiple regression techniques were used in this study to evaluate how responsive private rangeland lease rates have been to short-term (yearly) fluctuations in market conditions. Independent variables included yearling prices, cattle numbers, hay prices, production cost index, land prices, forage condition index, and the previous year's lease rate. Yearling prices lagged 1 year, hay prices, production cost index lagged 1 year, and lease rates lagged 1 year statistically $(P<0.10)$ explained lease rates. The previous year's lease rate was the most influential explanatory variable, with more than half of the previous year's lease price reflected in the current year's rate. Statistically significant $(P<0.10)$ differences in lease rates were also found between western regions.
\end{abstract}

Key Words: PRIA, federal grazing fee, livestock grazing, forage value index.

Average lease rates for cattle grazing on private land in the western United States have been collected and reported by the National Agricultural Statistical Service (NASS) for more than 3 decades. The private rangeland lease rate is the average price of monthly lease rates for private, nonirrigated grazing land on an animal unit month (AUM), cow-calf, and per head basis. Not only does the private rangeland lease rate provide valuable information to ranchers and land owners, but it has also been used historically as an indication of the fair market value for public land grazing leases (USDA/USDI 1977, USDA/USDI 1992).

The private rangeland lease rate for the 11-western states has been converted to an index known as the forage value index. The forage value index is typically calculated with 1964-1968 as the base period because of its use in updating the federal grazing fee. The current federal grazing fee formula (PRIA) utilizes a base "fair market value" of $\$ 1.23$ established in 1966 through the Western Livestock Grazing Survey (USDA/USDI 1977). The original proposal set forth by the Secretaries of the Interior and Agriculture in 1977 recommended the base fee be updated annually according to the percentage change in the forage value index. Congress ruled that the proposed grazing fee system would not be

\footnotetext{
Manuscript accepted 16 March 1996.
}

Las cuotas de arrendamiento por pastoreo en tierras privadas han sido empleadas históricamente como un indicador del precio de las cuotas de arrendamiento de tierras publicas para el apacentamiento de ganado en el Oeste de los Estados Unidos. El que estos precios, reflejan adecuadamente las fluctuaciones a corto plazo ha sido cuestionado tanto por legisladores como por especialistas. Técnicas de regresión múltiple fueron utilizadas en este estudio para evaluar como han-respondido las tasas de arrendamiento a las fluctuaciones a corto plazo (anuales) bajo las condiciones reales del mercado. Las variables independientes incluyeron los precios de animales añojos, volumenes de ganado, precios del forraje, indice del costo de produccion, costo de la tierra, indice de condicion de forraje, y la cuota de arrendamiento del ano anterior. Los resultados indican que los precios para animales anojos, precios del forraje, el indice de costo de producción y las tasas de arrendamiento, se rezagaron estadisticamente $(P<0.10)$ un año. La cuota de arrendamiento del año anterior fue la variable más determinante con mas de la mitad del percio de arrendamiento del año previo, reflejado en la cuota de arrendamiento del ano en curso. Diferencias estadisticamente significativas $(P<0.10)$ en las tasas de arrendamiento, también fueron encontradas entre las diversas regiones del oeste de los Estados Unidos.

equitable to permittees, in part because "...the proposed formula in no way incorporates factors which recognize the costs of production, beef prices, or the ranchers [sic] ability to pay" (U.S. Congress, House of Representatives 1978, p. 18). A technical committee assigned by the Bureau of Land Management (BLM) and the U.S. Forest Service (USFS) to study grazing fees concluded the forage value index adequately measured the long-term trend in grazing values, but they "questioned the ability of the index to reflect short-term instabilities that result during periods of disequilibrium" (USDA/USDI 1977, p. 3-34). For these reasons, the current PRIA formula uses 3 indices--forage value index, beef cattle price index and index of input prices-to update the annual public land grazing fee. The beef cattle price index and input price index have come to be called the "abilityto-pay" indices, and this is the justification now given for their inclusion in the PRIA formula (USDA/USDI 1992, p. 19).

Recent criticism has indicated that the beef cattle price index and input price index have biased the updating mechanism, resulting in a federal grazing fee that has lagged behind changes in the private grazing market (Brokken and McCarl 1987, Torell et al. 1993, USDA/USDI 1992). This can be seen in Fig. 1 where the forage value index is shown along with the PRIA base updat- 


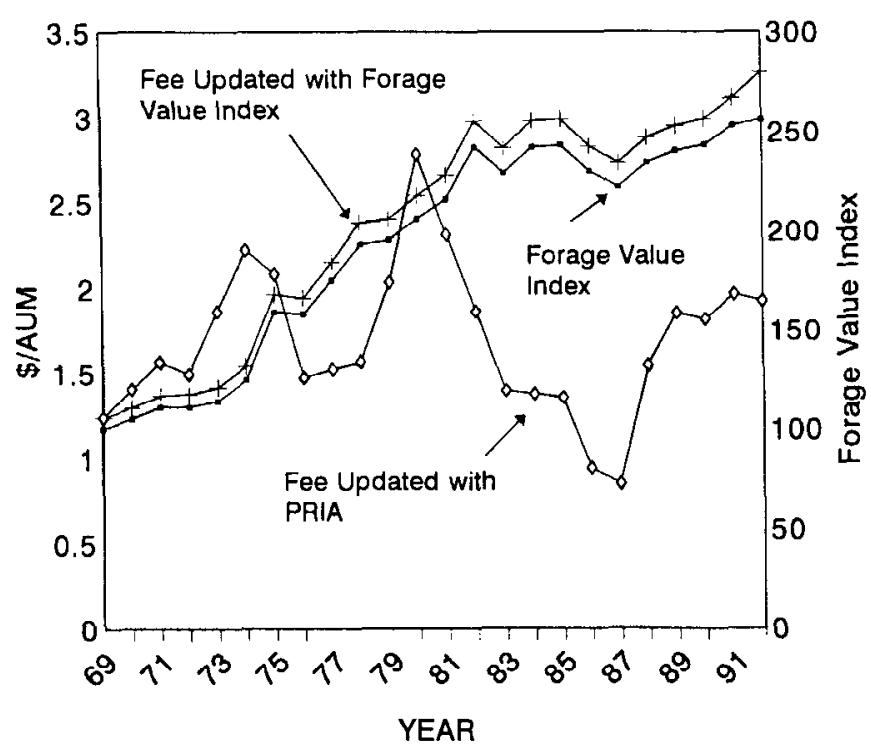

Fig. 1. Forage Value Index (FVI) and expected Federal grazing fee when PRIA base is updated by PRIA formula and when updated by F'VI alone, 1969 to 1992.

ed by the PRIA formula, and the PRIA base updated by the forage value index only. The PRIA formula has a floor of \$1.35/AUM that is not reflected in Fig. 1. While the PRIA formula has only been used to calculate fees since 1979 , data prior to 1979 are included to provide an extended examination. If the forage value index had been used exclusively to update the $\$ 1.23$ PRIA base, the grazing fee would have been \$3.26/AUM in 1992 compared to the actual fee of $\$ 1.92$.

Several authors have examined the relationship between the forage value index and various ability-to-pay indices. Brokken and McCarl (1987) used regression analysis to examine these relationships for national data and state data for Idaho, Montana, and New Mexico. They found a high degree of association between the forage value index and ability-to-pay indices, resulting in redundant terms being placed in the PRIA formula. Brokken and McCarl (1987) concluded that while more significant relationships existed between the forage value index and ability to pay indices on a national level, state level relationships differed significantly enough that it was "dubious to use a single formula across all states" (p. 64). Torell et al. (1989) also found the ability-to-pay indices in the PRIA formula had inappropriate index weights to adequately track private land lease rates in New Mexico and recommended the forage value index be used unaccompanied as an updating mechanism. Rimbey (Idaho State land grazing fee issues. Progress report presented to State of Idaho Land Board Subcommittee on Grazing Fees, July 30, 1990. Boise, Ida.) and Torell et al. (1993) obtained similar results for state level data. LaFrance and Watts (1995) also examined private grazing fees across states and found they could be explained largely by beef and hay prices, hay yields and the previous year's private grazing fee.

Recent proposed grazing fee regulations have included recommendations that federal grazing fees be updated exclusively by the forage value index, with the result being that ranchers' ability-to-pay is again being brought into question by various factions (USDI/USDA 1994, Hackett 1993). If private land lease rates are determined by demand and supply conditions, they should reflect the ranchers' ability-to-pay. As factors affecting the demand for forage vary, ranchers should correspondingly demand more or less forage and be willing to pay the associated prices. The same ability-to-pay factors that affect public land ranchers should affect private lease ranchers.

Along with criticism voiced concerning the suitability of the forage value index as a single revisor in the PRIA formula, questions have been raised that the forage value index is biased because of the collection procedures used (Rimbey et al. 1992). National Agricultural Statistical Service questionnaires concerning area lease rates are not directed exclusively at lessees or lessors of forage, but farmers/ranchers are asked what the going rate is in their area, regardless of whether they possess a lease. Considerable variability exists in the data and relatively little data are collected for determination of the forage value index compared to the vast area the index represents (Kearl 1989, Torell et al. 1989).

The objective of this study is to evaluate factors that influence the supply and demand of private rangeland lease rates in the 11western states and evaluate how responsive the private rangeland lease rate has been to short-term (yearly) fluctuations in market conditions. We hypothesize that yearly movements in private rangeland lease rates can be significantly explained by changes in supply and demand forces (ability-to-pay factors), and thus the forage value index embodies ability-to-pay factors and its use as a solitary revisor is equitable.

\section{Methods}

\section{Theoretical Model}

The price of private rangeland leases should theoretically be determined by interaction of the supply of, and demand for, those leases. As thc supply of private rangeland leases increases (decreases), ceteris paribus, the price of leases should decrease (increase). As the demand for private rangeland leases increases (decreases), ceteris paribus, the price of leases should increase (decrease).

According to economic theory, factors affecting the quantity supplied of an agricultural commodity include price of the commodity, prices of inputs it takes to create the commodity and technology available to do so, government policy, weather or growing conditions, prices of alternative products that could be raised, and the number of suppliers in the market (Workman 1986). This suggests that along with the positive effect the price of leases has on the quantity supplied, the price of inputs required to provide forage (e.g., land prices, interest rates, repairs, taxes, insurance and costs of services provided) should have an inverse relationship with the quantity supplied of private lease forage. The quantity supplied should be positively influenced by forage availability as determined by weather conditions and inversely related to the total number of leases available. While there are few alternatives (e.g., wildlife production or recreation) to grazing for the lessor to consider, the price of alternatives would be inversely related to the quantity of grazing leases supplied. Other external forces such as changes in technology (e.g., grazing systems, brush control practices, new forage species) and government policies could also influence the supply of rangeland leases.

Factors affecting the quantity demanded of an agricultural input include price of the input, prices of other factors used in the pro- 
duction process, expected price of the output and number of buyers. The quantity of private rangeland leases demanded, then, should be inversely related to the private rangeland lease rate and prices of inputs required to utilize the forage or those goods used commonly with private leases (e.g., price of livestock purchased to graze the lease, labor, veterinary services, marketing, hauling). Adverse financial conditions and expected lower prices for livestock grazing the lease would further have a dampening effect on demand. Prices of alternative feed sources such as hay, grains or public grazing permits would have a positive effect on the demand for private leases. The quantity of private leased forage demanded would also vary as tenure preferences of lessees change.

An additional way to ascertain the factors affecting private land lease rates is to examine the fashion in which they are determined. VanTassell and Burgener (1994) found the price a private land grazing lease bears is often determined through a negotiation process. In determining how much they could afford to pay for the grazing lease, about $43 \%$ of lessees in Wyoming stated an estimated break-even price had a modest to great influence on lease price. The factors involved in determining a grazing lease break-even price for a lessee and lessor have been identified by Bennetl (1973). Factors influencing the lessor's break-even price are land prices, costs of services provided, interest, repairs, taxes and insurance. Factors influencing the lessee's break-even price include prices of inputs such as livestock, labor, veterinary services, taxes, marketing, hauling, etc. Opportunity costs and a return to management are also expenses for both parties.

\section{Applied Model}

One of the problems in examining factors that influence the price of private rangeland grazing leases is that data concerning the quantity of leases supplied and quantity demanded do not exist. The impact of quantity supplied and demanded upon the private rangeland lease rate therefore cannot be determined directly. As a proxy for the quantity demanded, the number of cattle and calves in each state was used. While data concerning the number of leases available are not obtainable, the supply of forage as influenced by weather conditions and indicated by forage conditions may serve as an indicator of the overall quantity of forage. Cattle numbers should a priori have a positive impact on lease rates, while forage conditions are expected to have a negative impact on lease rates (e.g., better forage condition implies lower lease rates because of increased supply of forage).

Input expenses are important to both the lessor and lessee. Though actually a fixed expense, a fair return on deeded rangeland is a major part of the lessor's breakeven price and should have a positive influence on lease rates. While a successive rangeland price series does not exist, the farmland real-estate price was used as a proxy.

A major input for lessees is the expense of purchasing livestock. Livestock prices are also a good indicator of the financial condition of most ranchers. Cattle prices were chosen to represent livestock prices since the majority of private land leases in the west are occupied by cattle (Torell et al. 1993). Break-even values for cow-calf operators are primarily influenced by calf prices while yearling operations are influenced by calf prices at the beginning of the lease and yearling prices at the end of the lease period.

The production cost index, a composite index of input costs, was chosen to represent all other input expenses. The production cost index is an index if inputs not produced on the farm. As production costs increasc for lessors, their breakeven price should increase, while the opposite would be true for lessees. We hypothesize lessees would be influenced more by production expenses since they would bear most of these expenses. Input costs should a priori have a negative impact on lease rates.

Data concerning alternative uses of rangeland for lessors is not accessible, but alternative feed source data for lessees are available. While several alternative feed sources could be used, hay price was chosen as a proxy because hay is readily available to producers and is used as a near complete feed source by many.

Services provided by the lessor have been shown to be an important determinant of private rangeland lease rates (Rimbey et al. 1994, Torell and Bledsoe 1990). Data concerning services provided by the leases represented by the private rangeland lease rate were not available and thus were not examined in this analysis. Other factors such as technology and tenure preferences were also omitted because of the unavailability of appropriate data.

Once a private land grazing lease rate is determined, that rate becomes the basis of negotiation for future years. VanTassell and Burgener (1994) found that $50 \%$ of lessees surveyed stated the price paid for the lease in the previous year had a modest to great influence on the current year's lease rate and that $64 \%$ of lease agreements were only 1 year in duration. The previous year's lease rate was therefore included as a predictor of the current year's rate.

Virtually all economic decisions involve time. The determination of private grazing lease rates is no exception. VanTassell and Burgener (1994) found that $56 \%$ of contracts were negotiated within 3 months of the beginning of the grazing season and almost $80 \%$ were agreed upon within 6 months. It is therefore logical that lease rates are determined by some combination of observations of prices and conditions both in the past and present. Equations were therefore estimated using various combinations of lagged (historical) and current variables. Expected prices were represented by a naive model where prices in period t- 1 represent expected prices in period $\mathrm{t}$.

Differences in lease rates by state were examined by using intercept shifter variables in the regression framework. Equations were also estimated for each individual state to examine responsiveness of private land grazing rates to the independent variables on a state-by-state basis. The same independent variables hypothesized to be valid for the 11-state area were used as explanatory variables in the individual state equations.

\section{Data}

Time series for cattle prices, hay price, and lease rates were collected from various issues of Agricultural Prices (USDA/NASS 1962-1993). Data for the 11 western states from 1961 to 1992 were obtained from the December issue of Agricultural Prices (USDA/NASS 1962-1993). Yearling price is the average state price per $100 \mathrm{~kg}$ received by farmers for steers and heifers. Calf price is the average state price per $100 \mathrm{~kg}$ received by farmers for steer and heifer calves. Hay price is the season average state price per ton of all hay received by farmers. Lease rate is the average state grazing lease rate per animal unit month on privately owned land. The production cost index is defined as the U.S. index of production items with non-farm origin (USDA/NASS 1962-1993). The production cost index was 
not available prior to 1977 , so the producers price index (USDC 1962-1993) was used as a proxy to estimate the missing years $\left(\mathrm{R}^{2}=.98\right)$. Numbers of cattle is defined as the January 1 cattle and calves on farm inventory by state and was collected from various issues of Agricultural Statistics (USDA 1962-1993). Land value is the individual state farmland real-estate price per hectare collected from Agricultural Resources, Agricultural Land Values and Markets (ERS/USDA 1962-1993). Forage condition is expressed as a percent of the individual state 7 -month average (May-November) peak pasture and range feed condition and was obtained from the Livestock Marketing Information Center.

Prices were deflated using the Implicit Gross Domestic Product Deflator with 1992 being the base year (USDC 1962-1993) to express prices on a real instead of a nominal basis. Nominal price values a good (e.g., forage) at the price that prevailed when it was sold. Real price attempts to account for inflationary changes by valuing goods produced in different periods in constant dollars. This is accomplished by adjusting prices by a measure of price changes in the economy such as the Implicit Gross Domestic Product Deflator. For example, the Implicit Gross Domestic Product Deflator in 1992 was 100 and in 1980 was 59.21. The average Wyoming grazing lease price in 1980 was $\$ 8.37$ AUM and the lease price in 1992 was $\$ 9.93$ /AUM. To adjust the 1980 lease price to 1992 dollars so the value of the 2 products can be compared in constant dollars (i.e., adjusting for inflation), the calculation $\$ 8.37 / 59.21 * 100$ would be performed to obtain the 1980 lease rate of $\$ 14.14 / \mathrm{AUM}$ in 1992 dollars.

\section{Analysis}

Multiple regression techniques were used to explain variation in average lease rates for the 11-western states. Because the data set contains cross-sectional and time-series data, the classical linear regression assumptions may be violated. Kmenta (1986) states that cross-sectional observations will frequently produce regression disturbances that are mutually independent but heteroskedastic while time-series observations are typically autoregressive though not necessarily heteroskedastic. Durbin's- $h$ statistic (Greene 1993) was used to detect the presence of serial correlation and White's test (Greene 1993) was used to test for heteroskedasticity. Time Series Cross Section Regression (TSCSR), as developed by Parks (1967), was used to correct for heteroskedasticity and autocorrelation.

While heteroskedasticity is not a problem in individual state data, autoregressive disturbances are still a concern. Yule-Walker estimation procedures were accordingly used to correct for serial correlation in the error term for the individual state equations (Greene 1993).

Including all relevant livestock prices as independent variables would create a high degree of collinearity. Separate equations were therefore examined to determine if calf or yearling prices were more likely to influence lease rates.

Including intercept shifter variables (dummy variables) for each state has the potential of producing collinearity. Therefore, regional dummy variables were also developed and tested as a possible way to reduce collinearity. Regions were determined by sorting state lease rates in descending order and conducting a paired difference test (Neter et al. 1990) to determine regions. To detect collinearity among variables, condition indices were examined (Belsley et al. 1980).

\section{Results}

The average numinal and real private land grazing fee for each state from 1961-1992 is shown in Table 1. Variation in average state lease rates exists, with Arizona having the lowest real and nominal average at $\$ 9.63$ and $\$ 3.84 / A U M$, respectively, and California having the highest averages at $\$ 14.19$ and \$6.66/AUM, respectively. When the average state fees are ranked in descending order and a paired difference test conducted, 3 regions develop. Washington, Oregon, Idaho, and Utah comprise Region 1; Montana, Wyoming, Colorado, Nevada, and California constitute Region 2; and Arizona and New Mexico form Region 3.

As expected, the correlation coefficient between yearling prices and calf prices was high $(r=.868)$ and collinearity was created when the 2 prices were used together in an equation. Yearling prices (both lagged and current) maintained a better "fit" in the equations examined and therefore calf prices were discarded in favor of yearling prices. Determination of variables to be included was made by examining $R^{2}$ values and $t$-statistics in the Ordinary Least Square equations. For the Time Series Cross Sectional Regression equations, $t$-statistics were used since $R^{2}$ is not a valid statistic.

Table 1. Nominal and Real State Private Land Grazing Fee Statistics, 1961-1992'.

\begin{tabular}{|c|c|c|c|c|}
\hline State & Mean & Minimum & Maximum & $\begin{array}{c}\text { Standard } \\
\text { Deviation }\end{array}$ \\
\hline Arizona & $\begin{array}{c}9.63 \\
(3.84)\end{array}$ & $\begin{array}{c}3.65 \\
(2.52)\end{array}$ & $\begin{array}{l}16.49 \\
(7.19)\end{array}$ & $\begin{array}{c}3.08 \\
(1.26)\end{array}$ \\
\hline California & $\begin{array}{l}14.19 \\
(6.66)\end{array}$ & $\begin{array}{c}9.88 \\
(3.58)\end{array}$ & $\begin{array}{c}18.27 \\
(10.72)\end{array}$ & $\begin{array}{c}2.60 \\
(2.65)\end{array}$ \\
\hline Colorado & $\begin{array}{l}13.23 \\
(6.18)\end{array}$ & $\begin{array}{c}9.36 \\
(3.14)\end{array}$ & $\begin{array}{c}16.17 \\
(10.20)\end{array}$ & $\begin{array}{c}2.17 \\
(2.43)\end{array}$ \\
\hline Idaho & $\begin{array}{l}12.07 \\
(5.64)\end{array}$ & $\begin{array}{c}7.73 \\
(2.96)\end{array}$ & $\begin{array}{c}16.11 \\
(10.18)\end{array}$ & $\begin{array}{c}2.23 \\
(2.22)\end{array}$ \\
\hline Montana & $\begin{array}{l}13.35 \\
(6.44)\end{array}$ & $\begin{array}{c}9.61 \\
(2.55)\end{array}$ & $\begin{array}{c}18.51 \\
(11.86)\end{array}$ & $\begin{array}{c}2.07 \\
(3.01)\end{array}$ \\
\hline New Mexico & $\begin{array}{l}10.71 \\
(4.77)\end{array}$ & $\begin{array}{c}3.10 \\
(2.65)\end{array}$ & $\begin{array}{l}14.57 \\
(7.55)\end{array}$ & $\begin{array}{c}2.91 \\
(1.60)\end{array}$ \\
\hline Nevada & $\begin{array}{l}13.38 \\
(5.81)\end{array}$ & $\begin{array}{c}3.68 \\
(2.55)\end{array}$ & $\begin{array}{c}18.70 \\
(15.78)\end{array}$ & $\begin{array}{c}4.23 \\
(3.03)\end{array}$ \\
\hline Oregon & $\begin{array}{l}11.72 \\
(5.50)\end{array}$ & $\begin{array}{c}7.15 \\
(2.99)\end{array}$ & $\begin{array}{l}14.94 \\
(9.75)\end{array}$ & $\begin{array}{c}2.12 \\
(2.18)\end{array}$ \\
\hline Utah & $\begin{array}{l}12.42 \\
(5.79)\end{array}$ & $\begin{array}{c}7.24 \\
(2.74)\end{array}$ & $\begin{array}{l}14.95 \\
(9.94)\end{array}$ & $\begin{array}{c}2.23 \\
(2.37)\end{array}$ \\
\hline Washington & $\begin{array}{l}12.17 \\
(5.76)\end{array}$ & $\begin{array}{c}8.03 \\
(2.93)\end{array}$ & $\begin{array}{c}14.85 \\
(10.69)\end{array}$ & $\begin{array}{c}1.88 \\
(2.47)\end{array}$ \\
\hline Wyoming & $\begin{array}{l}13.51 \\
(6.36)\end{array}$ & $\begin{array}{c}7.64 \\
(2.86)\end{array}$ & $\begin{array}{c}16.36 \\
(10.50)\end{array}$ & $\begin{array}{c}2.23 \\
(2.68)\end{array}$ \\
\hline 11-State Avg. & $\begin{array}{l}12.82 \\
(5.30)\end{array}$ & $\begin{array}{c}8.73 \\
(3.01)\end{array}$ & $\begin{array}{l}15.00 \\
(9.45)\end{array}$ & $\begin{array}{c}1.92 \\
(2.06)\end{array}$ \\
\hline
\end{tabular}

Top number is in real dollars $(1992=100)$, number in parenthesis is in nominal dollars

To determine if the lagged or current year value of yearling, input, hay and land prices, as well as cattle numbers and condition scores should be used, lagged and current specifications of all variables were tried in combination with each other as 
explanatory variables of lease prices along with lagged lease price and region variables. This entailed examining $2^{6}$ or $64 \mathrm{com}-$ binations. Lagged yearling prices, lagged input price index, current year cattle numbers, current year hay prices, lagged land prices, lagged forage condition along with the lagged lease rate provided the best fit. Lagged and current specifications of land prices and range condition provided similar results. As anticipated, individual state dummy variables created collinearity among the independent variables, so regional variables were used. Ordinary least square equations developed using these variables are shown in Table 2. Parameter estimates are presented in Equation (1) when all independent variables are included and in Equation (2) when insignificant variables are omitted. For ordinary least square estimates, lagged yearling prices, cattle numbers, lagged land values and lagged forage condition estimates were insignificant $(\mathrm{P}<0.10)$.

Durbin's-h and White's test indicated the ordinary least square equations were heteroskedastic and autoregressive. The Time

Table 2. Regression Estimates of Private Land Grazing Fee, 1962-1992.

\begin{tabular}{|c|c|c|c|c|}
\hline Variable & $\begin{array}{l}\text { Equation (1) } \\
\text { OLS }\end{array}$ & $\begin{array}{l}\text { Equation (2) } \\
\text { OLS }\end{array}$ & $\begin{array}{l}\text { Equation (3) } \\
\text { TSCRS }\end{array}$ & $\begin{array}{l}\text { Equation (4) } \\
\text { TSCRS }\end{array}$ \\
\hline Intercept $^{2}$ & $\begin{array}{l}5.87 \\
(1.193)^{* * 3}\end{array}$ & $\begin{array}{l}6.37 \\
(0.804)^{* *}\end{array}$ & $\begin{array}{l}5.035 \\
(0.909)^{* *}\end{array}$ & $\begin{array}{l}4.58 \\
(0.782)^{* *}\end{array}$ \\
\hline $\begin{array}{l}\text { LYEARLING } \\
(\$ / 100 \mathrm{~kg})\end{array}$ & $\begin{array}{c}0.0029 \\
(0.003)\end{array}$ & & $\begin{array}{c}0.0047 \\
(0.002)^{*}\end{array}$ & $\begin{array}{c}0.0044 \\
(0.002)^{*}\end{array}$ \\
\hline $\begin{array}{l}\text { NUM } \\
\text { (no.) }\end{array}$ & $\begin{array}{c}0.0001 \\
(0.0001)\end{array}$ & & $\begin{array}{r}-0.00007 \\
(0.0001)\end{array}$ & \\
\hline $\begin{array}{l}\text { HAY } \\
\text { (\$/metric ton) }\end{array}$ & $\begin{array}{c}0.0117 \\
(0.004)^{* *}\end{array}$ & $\begin{array}{c}0.0131 \\
(0.004)^{* *}\end{array}$ & $\begin{array}{c}0.0096 \\
(0.003)^{* *}\end{array}$ & $\begin{array}{c}0.0101 \\
(0.003)^{* *}\end{array}$ \\
\hline LPCI & $\begin{array}{l}-0.0172 \\
(0.003)^{* *}\end{array}$ & $\begin{array}{l}-0.0183 \\
(0.002)^{* *}\end{array}$ & $\begin{array}{l}-0.0148 \\
(0.002)^{* *}\end{array}$ & $\begin{array}{l}-0.0140 \\
(0.002)^{* *}\end{array}$ \\
\hline $\begin{array}{l}\text { LLAND } \\
\text { (\$/ha) }\end{array}$ & $\begin{array}{c}-0.00004 \\
(0.0001)\end{array}$ & & $\begin{array}{c}0.000066 \\
(0.0001)\end{array}$ & \\
\hline $\begin{array}{l}\text { LCOND } \\
(\%)\end{array}$ & $\begin{array}{l}-0.0016 \\
(0.008)\end{array}$ & & $\begin{array}{l}-0.0024 \\
(0.005)\end{array}$ & \\
\hline $\begin{array}{l}\text { L.LEASE } \\
\text { (\$/AUM) }\end{array}$ & $\begin{array}{c}0.5020 \\
(0.045)^{* *}\end{array}$ & $\begin{array}{c}0.5027 \\
(0.044)^{* *}\end{array}$ & $\begin{array}{c}0.5505 \\
(0.042)^{* *}\end{array}$ & $\begin{array}{c}0.5642 \\
(0.040)^{* *}\end{array}$ \\
\hline R2 & $\begin{array}{c}0.495 \\
(0.247)\end{array}$ & $\begin{array}{l}0.645 \\
(0.186)^{* *}\end{array}$ & $\begin{array}{l}0.718 \\
(0.206)^{* *}\end{array}$ & $\begin{array}{l}0.594 \\
(0.116)^{* *}\end{array}$ \\
\hline $\mathrm{R} 3$ & $\begin{array}{l}-1.403 \\
(0.284)^{* *}\end{array}$ & $\begin{array}{l}-1.378 \\
(0.259)^{* *}\end{array}$ & $\begin{array}{l}-1.03 \\
(0.217)^{* *}\end{array}$ & $\begin{array}{l}-1.10 \\
(0.178)^{* *}\end{array}$ \\
\hline Adj $R^{2}$ & 0.746 & 0.748 & & \\
\hline Durbin's $h$ & $1.45^{4}$ & $1.29^{5}$ & & \\
\hline White's Test ${ }^{6}$ & 8,297 & 510 & & \\
\hline
\end{tabular}

Abbreviations: LYEARLING = lagged yearling price $(\$ / 100 \mathrm{~kg})$; NUM $=$ number of cattle and calves on farm, Jan 1; HAY = hay price (\$/metric ton); $\mathrm{LPCI}=$ lagged production cost index; LLAND = lagged price of farm land ( $\$ /$ ha); LCOND = lagged forage condition percentage; LLEASE (lagged private land grazing fee (\$/AUM); R2 = 1 if region 2, 0 otherwise; $R 3=1$ if region 3,0 otherwise; $O L S=$ ordinary least squares regression estimates; TSCSR $=$ time series cross section regression estimates.

${ }^{2}$ Coefficients can be intcrpreted as follows (see Equation 4): for every $\$ 1$ incrcase in yearling prices, lease rates increase by $\$ 0.0044$; for every $\$ 1$ increase in hay prices, lease rates increase by $\$ 0.0101$; for every 1 point increase in the production cost index, lease rates decrease by $\$ 0.014$; for every $\$ 1$ increase in last year's lease rate, lease rates increase by $\$ 0.5642$; the base lease rate for Region 1 is $\$ 4.58$; the base lease rate for Region 2 is $\$ 0.594$ more than Region 1; the base lease rate for Region 3 is $\$ 1.10$ less than Region 1.

${ }^{3}$ Values in parentheses are standard errors. SIngle and double asterisks indicate significance at $\mathrm{P}<.05$ and $\mathrm{P}<.01$, respectively.

${ }^{4}$ Critical value for rejecting $H_{0}$; no autocorrelation, is $D_{I}=1.675$ at $\alpha=0.05$.

${ }^{5}$ Critical value for rejecting $\mathrm{H}_{\mathrm{O}}$ : no autocorrelation, is $\mathrm{D}_{\mathrm{L}}=1.718$ at $\alpha=0.05$.

${ }^{6} \mathrm{Critical}$ value for rejecting $H_{\mathrm{o}}$ : no heterosked, asticity is $\chi^{2}=124.34$ at $\alpha=0.05$.
Series Cross Sectional Regression routine in SAS (SAS Institute, Inc. 1988) was used to correct for these conditions. The resulting models are shown as Equations (3) and (4) in Table 2.

When heteroskedasticity and autoregression are accounted for, private land grazing fees are positively influenced by lagged yearling prices, current hay prices, and the previous year's lease rate. Private land grazing fees are negatively influenced by the input price index. Using the 199211 -western state averages of $\$ 175.03 / 100 \mathrm{~kg}$ for lagged yearling prices, $\$ 81.13 /$ metric ton for hay, a 177 price cost index, and $\$ 8.63 / \mathrm{AUM}$ for lagged lease rate gives a 1992 lease rate for Region 1 of $\$ 8.53$ /AUM. Lagged yearling prices contributed $\$ 0.77$, hay prices contributed $\$ 0.82$, the price cost index contributed $-\$ 2.48$, and the previous year's lease rate contributed $\$ 4.87$ to the 1992 lease rate estimate for Region 1.

As seen in Equation (3), coefficients for cattle numbers, lagged forage condition scores and lagged land prices were not significantly different from zero $(\mathrm{P}<0.10)$. The data spanned nearly 3 cattle inventory cycles, yct cattlc inventory was not a statistically significant indicator of demand for grazing leases. Forage condition was similarly thought to be an indicator of forage supply and thus demand for grazing, but likewise was insignificant in explaining private land lease rates. On a regional basis the opposite has been found. Fowler et al. (1994) found a strong correlation between drought conditions in New Mexico and West Texas versus the lease rate for McGregor Range located in southeastern New Mexico. The McGregor Range is controlled by the Department of the Army, with the surface range forage administered by the BLM. The forage is auctioned by quasi-competitive bidding. Perhaps the aggregation of the forage condition index precludes it as a good indicator of forage supply in this model or conditions at the time the lease was negotiated never reflected the anticipated forage supply.

Insignificant coefficients for lagged land prices indicate that lessors don't consider fluctuations in the real estate market when determining private grazing lease rates. This indicates that many lessors may be satisfied with expected land appreciation returns if they can cover non-land cash and depreciation expenses (Oltmans 1995).

Region dummy variables were significant $(\mathrm{P}<0.01)$, indicating differences in private land grazing fees between regions. Base lease rates were $\$ 0.59$ higher in Region 2 than Region 1 and $\$ 1.10$ lower in Region 3 than Region 1. Lease rates in Arizona and New Mexico (Region 3) not only take into consideration lower quality forage, but also consider yearlong grazing versus the seasonal grazing common in most other western states.

Equation (1) was estimated individually for each state to examine responsiveness of private land grazing rates to the independent variables on a state-by-state basis. Yule-Walker estimation procedures were used to correct for serial correlation in the error term (Greene 1993). Coefficients and their significance for each state equation are presented in Table 3. For most states, fewer independent variables were significant in explaining variation in state private lease rates than when estimated with cross-sectional data. The index of prices paid for non-farm items was significant $(P<0.10)$ in 8 of the 11 state models and carried the expected sign. Hay prices were significant $(P<0.10)$ in 4 of the 11 state models while exhibiting the hypothesized positive sign. Lagged yearling price, cattle numbers, lagged land prices, lagged forage conditions and lagged lease rates were significant in 2 to 4 of the state equations. Lagged forage condition and lagged lease rate carried the hypothesized sign when the coefficients were statisti- 
Table 3. Yule-Walker Estimates of Private Land Grazing Rate (\$/AUM) for Each of the 11-Western States, $1962-1992$.

\begin{tabular}{|c|c|c|c|c|c|c|c|c|c|c|c|}
\hline Variable & Ariz. & Calif. & Colo. & Idaho & Mont. & N.M. & Nev. & Ore. & Utah & Wash. & Wyo. \\
\hline Intercept & $\begin{array}{l}17.23 \\
(9.76)^{*^{2}}\end{array}$ & $\begin{array}{l}16.46 \\
(6.40)^{* *}\end{array}$ & $\begin{array}{l}12.76 \\
(3.79)^{* * *}\end{array}$ & $\begin{array}{l}-3.75 \\
(3.40)\end{array}$ & $\begin{array}{l}-4.34 \\
(1.96)^{* *}\end{array}$ & $\begin{array}{l}20.56 \\
(3.73)^{* * *}\end{array}$ & $\begin{array}{c}3.26 \\
(12.82)\end{array}$ & $\begin{array}{c}3.13 \\
(4.80)\end{array}$ & $\begin{array}{l}14.55 \\
(7.50)^{*}\end{array}$ & $\begin{array}{c}7.09 \\
(4.26)\end{array}$ & $\begin{array}{l}11.30 \\
(4.45)^{* *}\end{array}$ \\
\hline $\begin{array}{l}\text { LYEARLING } \\
(\$ / 100 \mathrm{~kg})\end{array}$ & $\begin{array}{c}-0.024 \\
(0.019)\end{array}$ & $\begin{array}{c}0.017 \\
(0.012)\end{array}$ & $\begin{array}{c}0.006 \\
(0.007)\end{array}$ & $\begin{array}{c}0.012 \\
(0.007)^{*}\end{array}$ & $\begin{array}{l}0.015 \\
(0.003)^{* * *}\end{array}$ & $\begin{array}{l}-0.026 \\
(0.009)^{* * *}\end{array}$ & $\begin{array}{c}0.006 \\
(0.023)\end{array}$ & $\begin{array}{c}0.010 \\
(0.008)\end{array}$ & $\begin{array}{l}-0.009 \\
(0.01)\end{array}$ & $\begin{array}{l}-0.008 \\
(0.011)\end{array}$ & $\begin{array}{l}-0.005 \\
(0.006)\end{array}$ \\
\hline $\begin{array}{l}\text { NUM } \\
\text { (no.) }\end{array}$ & $\begin{array}{c}-0.004 \\
(0.005)\end{array}$ & $\begin{array}{l}-0.002 \\
(0.001)^{*}\end{array}$ & $\begin{array}{c}-0.001 \\
(0.001)\end{array}$ & $\begin{array}{l}0.003 \\
(0.001)^{* *}\end{array}$ & $\begin{array}{c}0.003 \\
(0.0004)\end{array}$ & $\begin{array}{l}-0.004 \\
(0.002)^{* *}\end{array}$ & $\begin{array}{c}0.005 \\
(0.016)\end{array}$ & $\begin{array}{c}0.005 \\
(0.003)\end{array}$ & $\begin{array}{c}0.001 \\
(0.006)\end{array}$ & $\begin{array}{c}0.005 \\
(0.003)\end{array}$ & $\begin{array}{l}-0.001 \\
(0.002)\end{array}$ \\
\hline LPCI & $\begin{array}{l}-0.062 \\
(0.032)^{*}\end{array}$ & $\begin{array}{l}-0.028 \\
(0.012)^{* *}\end{array}$ & $\begin{array}{l}-0.024 \\
(0.010)^{* *}\end{array}$ & $\begin{array}{c}0.005 \\
(0.010)\end{array}$ & $\begin{array}{c}0.009 \\
(0.005)\end{array}$ & $\begin{array}{l}-0.093 \\
(0.015)^{* * *}\end{array}$ & $\begin{array}{c}-0.001 \\
=(0.028)\end{array}$ & $\begin{array}{l}-0.021 \\
(0.009)^{* *}\end{array}$ & $\begin{array}{l}-0.039 \\
(0.017)^{* *}\end{array}$ & $\begin{array}{l}-0.025 \\
(0.011)^{* * *}\end{array}$ & $\begin{array}{l}-0.033 \\
(0.011)^{* * *}\end{array}$ \\
\hline $\begin{array}{l}\text { LLAND } \\
\text { (\$/ha) }\end{array}$ & $\begin{array}{c}0.001 \\
(0.005)\end{array}$ & $\begin{array}{c}0.001 \\
(0.001)\end{array}$ & $\begin{array}{c}0.001 \\
(0.001)\end{array}$ & $\begin{array}{l}-0.001 \\
(0.001)^{* *}\end{array}$ & $\begin{array}{l}-0.003 \\
(0.001)^{* *}\end{array}$ & $\begin{array}{l}0.013 \\
(0.003)^{* * *}\end{array}$ & $\begin{array}{l}-0.013 \\
(0.008)^{*}\end{array}$ & $\begin{array}{l}-0.0002 \\
(0.001)\end{array}$ & $\begin{array}{r}0.0004 \\
(0.001)\end{array}$ & $\begin{array}{c}0.001 \\
(0.001)\end{array}$ & $\begin{array}{c}0.004 \\
(0.003)\end{array}$ \\
\hline $\begin{array}{l}\text { LLCOND } \\
(\%)\end{array}$ & $\begin{array}{c}0.023 \\
(0.049)\end{array}$ & $\begin{array}{c}0.005 \\
(0.024)\end{array}$ & $\begin{array}{l}-0.044 \\
(0.018)^{* *}\end{array}$ & $\begin{array}{l}-0.001 \\
(0.012)\end{array}$ & $\begin{array}{c}0.011 \\
(0.011)\end{array}$ & $\begin{array}{c}0.017 \\
(0.021)\end{array}$ & $\begin{array}{c}0.065 \\
(0.069)\end{array}$ & $\begin{array}{l}-0.043 \\
(0.025)^{*}\end{array}$ & $\begin{array}{c}0.011 \\
(0.027)\end{array}$ & $\begin{array}{l}-0.051 \\
(0.032)\end{array}$ & $\begin{array}{l}-0.001 \\
(0.019)\end{array}$ \\
\hline $\mathrm{R}^{2}$ & 0.724 & 0.784 & 0.929 & 0.914 & 0.920 & 0.905 & 0.592 & 0.868 & 0.697 & 0.688 & 0.869 \\
\hline
\end{tabular}

Abbreviations: LSTEER = lagged yearling price $(\$ / 100 \mathrm{~kg}) ; \mathrm{NUM}=$ number of cattle and calves on farm, Jan $1 ;$ HAY = hay price $(\$ /$ metric ton $) ; \mathrm{LPI}=$ lagged production cos index; LLAND = lagged price of farm land $(\$ / \mathrm{ha}) ; \mathrm{LCOND}=$ lagged range condition percentage; LLEASE (lagged private land grazing fee $(\$ / A U M) ; \rho_{1}=$ autoregressive parameter estimate for lag 1 .

cally different from zero $(\mathrm{P}<0.10)$. None of the individual state equations maintained the same significant explanatory variables as the cross-sectional equation.

\section{Conclusions}

It is difficult to tell how responsive private land lease rates should be to "costs of production, beef prices, or the ranchers [sic] ability to pay" (U.S. Congress, House of Representatives 1978, p.18) so that the forage value index adequately reflected "short-term instabilities" (USDA/USDI 1977, p. 3-34). Results of this study show that private grazing land lease rates adjust yearly to several factors that affect the profitability of ranchers. Lagged yearling prices and input prices, current hay prices, and the previous year's lease rate are significant $(\mathrm{P}<0.10)$ in explaining the variation in the current year's lease rate. The previous year's lease rate is the most influential explanatory variable, with more than half the variability in the current year's rate explained by the previous year's lease price.

This study supports findings by Brokken and McCarl (1987), Torell et al. (1989), and Torell et al. (1993) that beef prices and input costs are already captured in private land lease rates, both theoretically and empirically. As previously discussed, the preceding year's lease rate was the major factor explaining the current year's rate. This suggests use of the forage value index in updating public lease rates. We therefore recommend that a new base be established that equates the total costs of grazing on leased private lands and the total costs of grazing on public lands, and that this base be updated yearly by the forage value index.

When the model developed for the cross-sectional data (Equation 1) was estimated on a state-by-state basis, results were not consistent between states and the theoretical model did not perform consistently. Perhaps concerns that individual state esti- mates of private land lease rates are not reliable unless combined to form a west-wide estimate (Kearl 1989, Torell et al. 1993) are reflected in these results. An increased sample size and a survey directed towards lessors and lessees of private rangeland forage are recommended.

As previously discussed, several variables that theoretically influence the price paid for private rangeland leases were not included in this study because of their unavailability. Cross-sectional and time-series data that includes variables such as services provided, non-fee costs, and quantity supplied and demanded would perhaps shed further light on the value of forage dilemma.

\section{Literature Cited}

Belsley, D.A., E. Kuh, and R.E. Welsch. 1980. Regression diagnostics: Identifying influential data and sources of collinearity. John Wiley \& Sons, New York, N.Y.

Bennett, M. 1973. Developing equitable pasture leases. J. of the Amer. Society of Farm Managers and Rural Appraisers. 37:37-39.

Brokken, R.F. and B.A. McCarl. 1987. A theoretical evaluation of fee systems for private grazing on federal lands. USDA-ERS Report No. 570. Washington, D.C.

Economic Research Service and U.S. Department of Agriculture (ERS/USDA). 1962-1992. Agricultural resources, agricultural land values and markets. Washington D.C.: Government Printing Office. Various issues.

Fowler, J.M., L.A. Torell, and G. Gallaclier. 1994. Competitive pricing for the McGregor Range: Implications for federal grazing fees. J. Range Manage. 47:155-158.

Greene, W.H. 1993. Econometric analysis. Macmillan Publishing Company, New York, N.Y.

Hackett, D. 1993. Records show existing fee reflects rancher ability to pay. Casper Star Tribune. Oct. 30. Casper. Wyo.

Kearl, W.G. 1989. Critical review and appraisal of federal grazing fee studies. University of Wyoming, Agr. Exp. Sta. ,B-930. Laramie, Wyo.

Kmenta, J. 1986. Elements of econometrics. Macmillan Company, New York, N.Y. 
LaFrance, J.T. and M.J. Watts. 1995. Public grazing in the West and "Rangeland Reform '94". Amer. J. Agr. Econ. 77:447-461.

Neter, J., W. Wasserman, and M.H. Kutner. 1990. Applied linear statistical models. Irwin Company, Boston, Mass.

Oltmans, A.W. 1995. Why farmland cannot, will not and should not pay for itself. J. Amer. Society of Farm Managers and Rural Appraisers. 59:57-67.

Parks, R.W. 1967. Efficient estimation of a system of regression equations when disturbances are both serially and contemporaneously correlated. J. of the Amer. Statistical Assoc. 62:500-509.

Rimbey, N.R., R. Krebill-Prather, and J.E. Carlson. 1992. Range and pasture forage: What's it worth? Univ. of Idaho Agr. Exp. Sta. Res. Ser. 92-3. Moscow, Ida.

Rimbey, N.R., L.A. Torell, E.T. Bartlett, and L.W. VanTassell. 1994. Private grazing lease arrangement and their application to market price comparisons. J. Amer. Society of Farm Managers and Rural Appraisers. $58: 125-129$.

SAS Institute, Inc. 1988. SAS/ETS users guide, Version 6.1. SAS Institute, Inc., Cary, N.C.

Torell, L.A. and F.N Bledsoe. 1990. 1989 New Mexico private grazing lease arrangements and costs. New Mexico State Univ. Agr. Exp. Sta. Res. Rpt. 651. Las Cruces, N.M.

Torell, L.A., S. Ghosh, and J.M. Fowler. 1989. Economic considerations for setting grazing fees on New Mexico State Trust Lands. New Mexico State Univ. Agr. Ext. Sta. Spec. Rpt. 81. Las Cruces, N.M.

Torell, L.A., L.W. VanTassell, N.R. Rimbey, E.T. Bartlett, T. Bagwell, P. Burgener, and J. Coen. 1993. The value of public land forage and the implications for grazing fee policy. New Mexico St. Univ. Res. Bull. 767. Las Cruces, N.M.
U.S. Congress, House of Representatives. 1978. Improving the range conditions of the public rangelands. House Rpt No. 95-1122. Washington, D.C.

U.S. Department of Agriculture. 1962-1993. Agricultural statistics. Washington, D.C. Various issues.

U.S. Department of Agriculture, Forest Service, and U.S. Department of Interior, Bureau of Land Management (USDA/USDI). 1977. Study of fees for grazing livestock on Federal lands. A report from the Secretaries of Agriculture and Interior. Washington, D.C.

U.S. Department of Agriculture, Forest Service, U.S. Department of Interior, Bureau of Land Management (USDA/USDJ). 1992. Grazing fee review and evaluation update of the 1986 final report: A report from The Secretaries of Agriculture and Interior. Washington, D.C.

U.S. Department of Interior, Bureau of Land Management, U.S. Department of Agriculture, Forest Service (USDI/USDA). 1994 Rangeland Reform ' 94 - final environmental impact statement. Washington, D.C

U.S. Department of Agriculture, National Agricultural Statistics Service (USDA/NASS). 1962-1993. Agricultural prices. Washington, D.C. Various Issues.

U.S. Department of Commerce (USDC). 1962-1993. Survey of current business. Washington, D.C. Various issues.

VanTassell, L.W. and P. Burgener. 1994. Private rangeland leases in Wyoming. Dept. of Agr. Econ., Univ. of Wyoming, AE 94-1. Laramie, Wyo.

Workman, J.P. 1986. Range economics. MacMillan Publ. Co., New York, N.Y. 